\title{
TEACHING PEDESTRIAN UNTUK ANAK SEKOLAH DASAR DI RUANG PEDESTRIAN MENUJU KE SEKOLAH SD PEDALANGAN, BANYUMANIK
}

\author{
Anita Ratnasari $\mathbf{R}^{1}$ \\ Diah Intan Kusumo Dewi ${ }^{2}$ \\ Departemen Perencanaan Wilayah dan Kota Fakultas Teknik Universitas Diponegoro ${ }^{1,2}$ \\ Penulis Korespondensi e-mail : anita.ratnasari.r@pwk.undip.ac.id
}

\begin{abstract}
Walking activities are currently eroded due to the increasingly dominant use of motorized modes. The high use of motorized vehicles is often dangerous for children. Pedalangan Elementary School located in Banyumanik District is an area affected by increased activity due to the stipulation of the Tembalang District as an Education Area. The high movement or volume of traffic in the corridor is not balanced with adequate road width. It will increase the risk of accidents for elementary school students. The purpose of this study is to provide education to students of Pedalangan Elementary School about the ethics of walking on pedestrian paths, crossing roads and manners in open spaces (parks) which are expected to influence the improvement of students' habits to walk to school or public spaces. This study uses qualitative methods with data collection methods in the form of observation. The results of this study are students' understanding of the ethics of walking on pedestrian paths, crossing and manners in the park increased after education about road safety. Keywords : Teaching Pedestrian, Student of Elementary School, Pedestrian Ethics
\end{abstract}

ABSTRAK

Kegiatan berjalan kaki saat ini mulai terkikis karena semakin dominannya penggunaan kendaraan bermotor. Tingginya penggunaan kendaraan bermotor seringkali membahayakan bagi anak-anak. Sekolah Dasar Pedalangan yang terletak di Kecamatan Banyumanik merupakan kawasan yang terkena dampak peningkatan aktivitas akibat ditetapkannya Kecamatan Tembalang sebagai Kawasan Pendidikan. Tingginya pergerakan atau volume lalu lintas di koridor tersebut tidak diimbangi dengan pembangunan infrastruktur jalan yang memadai, sehingga dapat meningkatkan resiko kecelakaan bagi siswa Sekolah Dasar. Tujuan penelitian ini adalah memberikan pembelajaran (edukasi) kepada siswa SD Pedalangan tentang etika berjalan di jalur pejalan kaki dan menyeberang jalan diharapkan dapat mempengaruhi peningkatan kebiasaan siswa untuk melakuakan pergerakan berangkat dan pulang sekolah dengan berjalan kaki. Penelitian ini menggunakan metode kualitatif dengan metode pengumpulan data berupa observasi. Hasil penelitian ini adalah pemahaman siswa tentang etika berjalan kaki di jalur pejalan kaki dan menyeberang jalan kaitannya dengan edukasi tentang keselamatan di jalan.

Kata Kunci : Teaching Pedestrian, Anak sekolah dasar, Etika pejalan kaki. 


\section{PENDAHULUAN}

Teaching pedestrian adalah suatu kegiatan pembelajaran yang bertujuan untuk memberikan informasi dan pemahaman tentang etika berjalan di jalur pejalan kaki kepada masyarakat sebagai pengguna jalur pejalan kaki (Miller, Austin, \& Donrohn, 2004; Page, Iwata, \& Neef, 1976). Berjalan kaki merupakan kegiatan yang sudah dilakukan dari zaman dahulu untuk bekerja, rekreasi, berolahraga dan sebagainya. Sirkulasi perpindahan orang atau manusia dari satu tempat ke titik asal ke tempat lain sebagai tujuan dengan berjalan kaki disebut dengan pedestrian (Rubenstein, 1992). Kegiatan berjalan kaki saat ini mulai terkikis karena semakin dominannya penggunaan moda bermotor. Hal ini dapat dipahami penyebab orang lebih memilih menggunakan mobil/sepeda motor karena merasa diuntungkan dalam hal biaya, tingkat fleksibilitas, kenyamanan, waktu perjalanan dan perlindungan terhadap cuaca (Gatersleben \& Uzzell, 2007). Tingginya penggunaan kendaraan bermotor seringkali membahayakan bagi anak-anak dan remaja karena ruangruang perkotaan didominasi oleh kendaraan dan faktor keselamatan mereka terganggu. Volume lalu lintas adalah faktor risiko yang sangat penting untuk cedera di kalangan pejalan kaki anak (Peden et al., 2004; Jermprapai \& Srinivasan, 2014). Anak-anak dan orang tua adalah kelompok pejalan kaki yang paling rentan (Peden et al., 2004; Holm, Jaani, Eensoo, \& Piksööt, 2018; Schwebel et al., 2018; Wang, Tan, Schwebel, Shi, \& Miao, 2018)

Ketertarikan remaja menggunakan kendaraan bermotor yang semakin tinggi yang tidak diimbangi pengetahuan keselamatan berkendara menambah resiko kecelakaan di jalan raya. Penggunaan kendaraan bermotor yang cukup tinggi ini juga menghasilkan emisi dan polusi di perkotaan yang menyebabkan masalah lingkungan (Bull, 2004). Masalah lingkungan yang muncul seperti polusi udara yang diperburuk dengan pengurangan RTH di sekitar kawasan permukiman, jalur transportasi utama sering macet, kecelakan serta permasalahan lalu lintas lainnya yang belum dapat diantisipasi/dikelola dengan baik juga dipengaruhi oleh pesatnya pembangunan di Kawasan Tembalang yang menjadi pusat kawasan pendidikan (Samadikun, Sudibyakto, Setiawan, \& Rijanta, 2014). Ruang-ruang di Kawasan Tembalang dikembangkan sebagai fungsi perdagangan, kos-kosan, warung dan bangunan lain yang megurangi fungsi badan jalan yang akhirnya mengurangi ruang-ruang pejalan kaki di kawasan tersebut. Fungsi jalan tersebut pada perkembangan selanjutnya mengalami diferensiasi, yaitu sebagai tempat pergerakan kendaraan (automobile) semakin menguat, sedangkan fungsi lain seperti jalur pejalan kaki yang mendukung pergerakan dan 
mobilitas masyarakat kota tersisihkan atau hilang (R.Bishop, 1989). Salah satu penyebab terganggunya aksesibilitas dan kenyamanan pejalan kaki di area pedestrian kawasan Tembalang adalah kawasan yang kurang teduh dan rindang, meningkatnya asap kendaraan bermotor, penataan parkir yang kurang baik bahkan terdapat alih fungsi menjadi lahan parkir atau tempat PKL, serta jaur pejalan kaki yang buruk dan tidak rata (Ujianti, 2012). Perubahan ini berdampak tidak hanya pada perubahan persepsi terhadap pemilihan moda transportasi tetapi sampai pada kebijaksanaan dalam perencanaan dan menjadi domain bagi perencana transportasi dengan pendekatan tekniknya.

Banyaknya masalah lingkungan yang muncul karena pembangunan yang pesat di perkotaan terutama di kawasan Tembalang menyebabkan pergerakan dengan berjalan kaki menjadi kebutuhan dan dikenalkan kembali dengan berbagai upaya. Upaya pengenalan moda berjalan kaki rupanya hanya terfokus pada perbaikan pedestrian dan belum mampu mendorong perilaku masyarakat untuk berjalan kaki terutama bagi remaja dan anak-anak. Banyaknya pusat pendidikan di Kawasan Tembalang seharusnya menjadikan kawasan ini ramah lingkungan karena banyak pelajar dan mahasiswa sehingga diperlukan upaya untuk meningkatkan kesadaran dan minat siswa untuk menerapkan moda transportasi ramah lingkungan seperti berjalan kaki di lingkungan sekolah maupun luar sekolah untuk keberlanjutan bersama. Mengenalkan dan mengajarkan moda berjalan kepada kelompok siswa SD Pedalangan merupakan upaya menggerakan dan mendorong minat siwa untuk memanfaatkan moda transportasi yang ramah lingkungan sejak dini.

Memberikan pemahaman tentang etika berjalan kaki, dan menyeberang jalan kepada anak sekolah di Cina dapat mengurangi resiko kecelakanaan (Dong et al., 2010). Kondisi infrastruktur jalan juga mempengaruhi keselamatan anak-anak ketika berjalan di area pedestrian. Infrastruktur jalan yang tidak memadai dan kurangnya pengawasan kepada anak-anak menjadi penyebab utama kematian anak-anak di Afrika Selatan (Koekemoer, Gesselleen, Niekerk, Govender, \& As, 2017). Amerika telah mampu meningkatkan kebiasaan berjalan dan bersepeda pada anak-anak usia sekolah melalui program SRTS (Safe Routes to School) dengan membangun trotoar, jalur sepeda, dan membuat perlintasan yang aman agar anak-anak dapat bepergian ke sekolah dengan lebih aman (DiMaggio, Frangos, \& Li, 2016).

Sekolah Dasar Pedalangan terletak di Kecamatan Banyumanik atau bagian Selatan Kota Semarang yang melewati koridor Jalan Prof. Sudarto-Sirojudin-Klentengsari. Keberadaan Sekolah Dasar Pedalangan yang terletak di kawasan Banyumanik secara tidak 
langsung mempengaruhi perkembangan kawasan, terlihat dari semakin banyaknya aktivitas penujang kegiatan pendidikan seperti kemunculan permukiman baru, kegiatan perdagangan dan jasa untuk pemenuhan kebutuhan mahasiswa di Kawasan Tembalang, dan sekolah-sekolah baru sebagai akibat peruntukan fungsi kawasan tembalang sebagai kawasan pendidikan. Kemunculan berbagai aktivitas tersebut menjadikan koridor tersebut berperan penting dalam perkembangan perekonomian di Kawasan Tembalang. Adanya kawasan komersial menyebabkan penggunaan lahan yang menghasilkan lalu lintas, menarik lebih banyak kendaraan, sehingga risiko kecelakaan pejalan kaki anak meningkat (Hwang, Joh, \& Woo, 2017; Dumbaugha, Li, \& Joh, 2013; Jermprapai \& Srinivasan, 2014). Kawasan pendidikan sebagai daya tarik utama akan memunculkan pergerakan menuju tempat bekerja atau tempat belajar. Tingginya pergerakan atau volume lalu lintas di koridor tersebut tidak diimbangi dengan lebar jalan yang memadai sangat berbahaya bagi siswa Sekolah Dasar, khususnya SD Pedalangan. Terpilihnya siswa sekolah dasar sebagai subjek penelitian karena siswa memiliki intensitas pergerakan yang tinggi ke sekolah dalam upaya peningkatan kesadaran berjalan kaki sejak dini.

\section{METODOLOGI}

Penelitian ini menggunakan metode kualitatif dengan metode pengumpulan data berupa observasi, yaitu mencatat dan memperhatikan tentang perilaku dan kegiatan subjek penelitian dan wawancara (Creswell, 2014). Siswa sekolah dasar yang dijadikan sebagai subjek pada penelitian ini adalah siswa kelas lima SD Pedalangan Kecamatan Banyumanik, Kota Semarang, perilaku siswa merupakan objek dalam penelitian ini. Penelitian ini dilakukan dengan membagi siswa menjadi enam kelompok yang dibantu dengan enam fasilitator sebagai pendamping siswa untuk mencari informasi mengenai etika berjalan kaki dan menyebrang jalan. Setiap fasilitator mendampingi empat sampai dengan lima siswa untuk mengetahui dan mengamati perilaku masing-masing siswa selama proses pembelajaran. Penting bagi fasilitator untuk mengenali perilaku anak-anak sebelum mengajar mereka cara mereka seharusnya bersikap (Grayson, 1981). Selanjutnya, siswa dapat berinteraksi dan berdiskusi secara langsung kepada fasilitator dikelompoknya selama proses pemberian materi dan observasi dilakukan. 


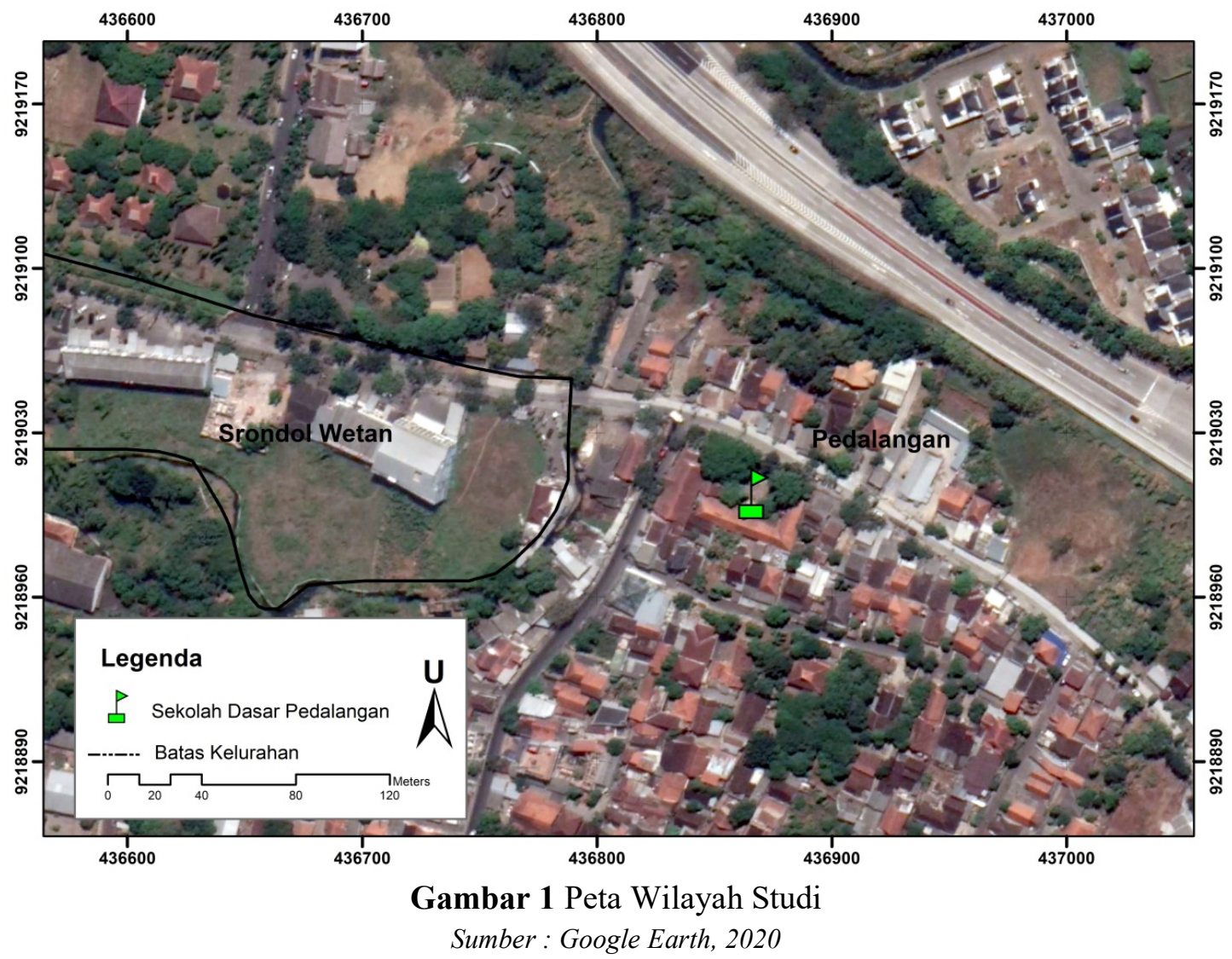

Proses pembelajaran dilakukan dengan melakukan ceramah diskusi (peer group) Pengembangan Kebiasaan Berjalan Kaki untuk Peningkatan Sekolah yang Ramah Lingkungan di SD Pedalangan Kecamatan Banyumanik, Kota Semarang. Materi yang diberikan berkaitan dengan etika berjalan kaki dan menyebrang jalan melalui pemberian materi dari fasilitator (dosen dan mahasiswa Universitas Diponegoro). Setelah materi selesai disampaikan, semua murid melakukan praktek berjalan kaki dan menyebrang jalan di jalan raya untuk mengimplementasikan materi yang telah disampaikan. 

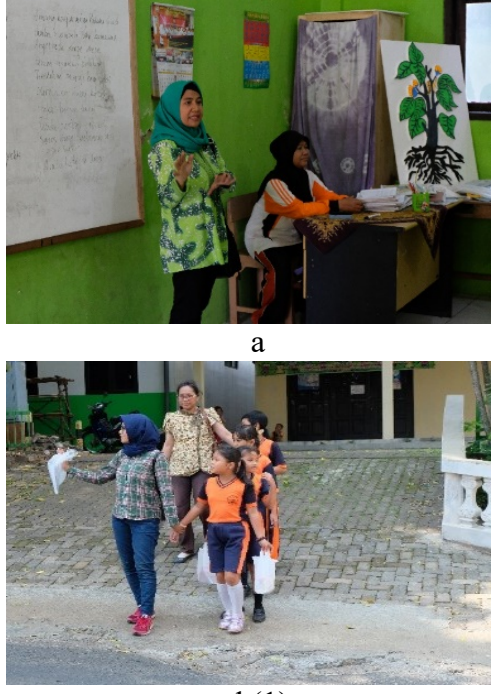

$\mathrm{d}(1)$
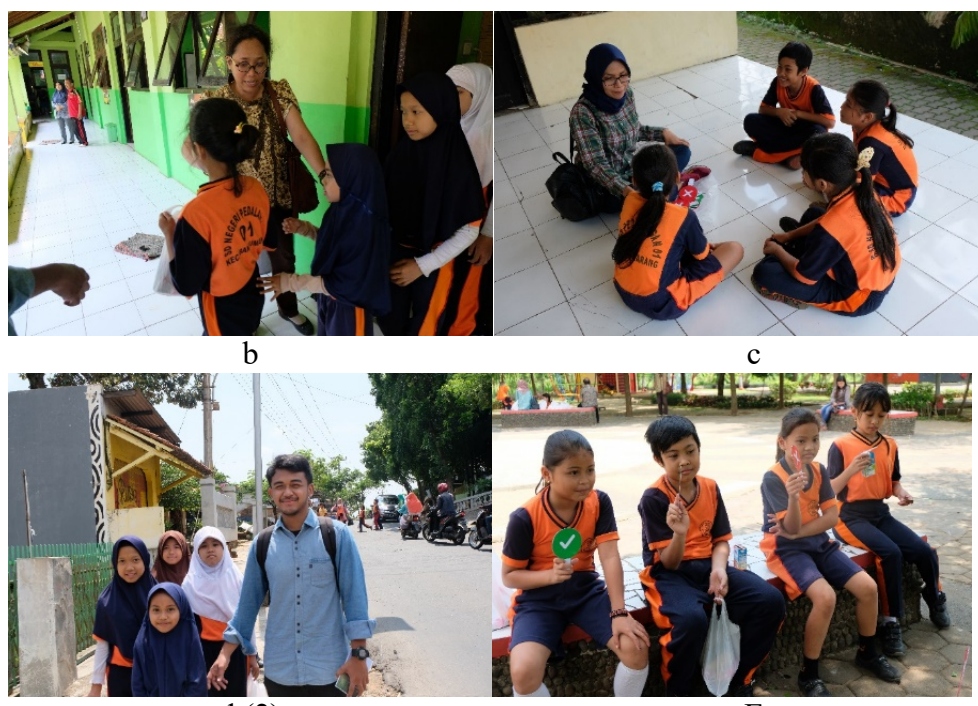

$\mathrm{d}(2)$

E

Gambar 2 2a. Pemberian materi awal, 2b. Siswa diajak keluar kelas bersama masing - masing fasilitator, 2c. Diskusi dengan fasilitator, 2d(1)(2). Praktek berjalan kaki dan menyebrang jalan di jalan raya, 2e. Kuis

Sumber : Dokumen Penulis, 2020

\section{HASIL DAN PEMBAHASAN}

Usia anak memengaruhi karakteristik perilaku pejalan kaki, resiko, dan keselamatan pejalan kaki (Zeedyk dan Kelly 2003; Wang et al. 2018). Sosialisasi dan pelatihan tentang etika berjalan dan menyebrang jalan kepada anak sekolah terbukti efektif untuk mengajarkan keterampilan keselamatan pejalan kaki kepada anak TK hingga SD kelas enam (Miller et al., 2004). Edukasi tentang etika berjalan di jalur pedestrian dan menyebrang jalan dilakukan dengan melakukan penyampaian materi secara umum, pembagian grup siswa, dan praktik implementasi materi ke lapangan secara langsung. Penyampaian materi awal tentang etika berjalan di jalur pejalan kaki dan menyeberang jalan kepada siswa dilakukan didalam kelas. Materi yang diberikan dalam bentuk poster yang menarik agar siswa tertarik untuk membaca dan memahami materi yang akan disampaikan. Materi yang diberikan kepada siswa SD Pedalangan dalam teaching pedestrian meliputi memperhatikan rambu lalu lintas, menjaga sopan dan santun, berhati hati terhadap kendaraan, berjalan di sebelah kiri, tidak bersenda gurau di jalan, tidak membuang sampah sembarangan, berhati - hati dengan orang yang tidak dikenal, dan tidak berjalan secara berkerumun.

Setelah materi utama diberikan, metode pembelajaran dilakukan dengan cara ceramah diskusi (peer group) oleh fasilitator yang dilaksanakan diluar kelas. Fasilitator 
memimpin diskusi selama proses pembelajaran dan berinteraksi kepada siswa dengan memberikan pertanyaan - pertanyaan tentang etika berjalan dan menyebrang jalan. Diskusi dilakukan bertujuan untuk membuat siswa tertarik untuk memahami lebih mendalam tentang etika berjalan dan menyebrang jalan.

Setelah dilakukan proses pembelajaran melalui diskusi selesai, siswa SD Pedalangan telah memahami etika berjalan dan menyeberang jalan. Pemahaman ini diketahui berdasarkan jawaban siswa atas pertanyaan yang diberikan oleh fasilitator selama proses diskusi. Siswa SD. Agenda dilanjutkan dengan mempraktikan materi yang telah didiskusikan dengan mengajak siswa keluar sekolah dan mengimplementasikan materi yang telah didiskusikan.

Gambar 3 Diskusi antara fasilitator dan siswa

(Setiap 4-5 murid memiliki 1 fasilitator yang akan menjelaskan etika berjalan di jalur pejalan kaki) Sumber : Dokumen Penulis, 2020

Siswa SD Pedalangan mengerti tentang etika berjalan kaki seperti harus memperhatikan rambu lalu lintas, menjaga sopan dan santun, berhati-hati terhadap kendaraan, berjalan di sebelah kiri, dilarang membuang sampah sembarangan dan berhatihati dengan orang yang tidak dikenal. Etika - etika tersebut didapatkan dari nasihat orang tua siswa yang diberikan kepada siswa ketika mereka akan pergi bermain/berangkat ke sekolah. Siswa juga melihat cara berjalan orang dewasa disekitar mereka ketika berjalan dijalur pejalan kaki dan menyeberang jalan.

Teaching pedestrian mengajarkan siswa untuk membiasakan mengucap salam dan atau memberikan senyuman kepada orang yang sedang berpapasan kepada mereka di jalan raya maupun di jalur pejalan kaki. Siswa juga diberikan pemahaman untuk melakukan hal ini ketika akan mendahului orang tua atau orang yang berkebutuhan khusus lain. Pemahaman siswa tentang etika menjaga sopan santun dijalan semakin bertambah setelah dilakukan pelatihan ini. Siswa juga telah memahami untuk tidak menerima barang atau tawaran dari orang tidak dikenal dengan harus tetap bersikap sopan. 
Namun, hal buruk yang masih sering dilakukan siswa adalah masih bersenda gurau di jalan dan berjalan secara berkerumun. Hal ini disebabkan karena siswa sering berangkat/pulang sekolah bersama dengan teman sepermainannya. Melalui pelatihan etika berjalan ini, siswa SD Pedalangan diberikan pemahaman lebih mendalam tentang seluruh etika berjalan di jalur pejalan kaki.

Ketika praktek implementasi materi, siswa langsung dapat menerapkan etika berjalan sesuai dengan materi yang telah diberikan. Saat berjalan kaki siswa langsung memposisikan diri berada di sisi kiri dari jalan raya, mereka mengerti hal ini dilakukan untuk menjaga keamanan mereka dan pejalan kaki lain. Siswa tidak lagi berjalan berkerumun, mereka berjalan lebih tertib secara berbanjar.

Kendala yang dihadapi selama proses implementasi materi tentang etika ketika berjalan dan menyebrang jalan adalah siswa masih sering bersenda gurau ketika berjalan di jalur pejalan kaki. Menyiasati hal tersebut, fasilitator mengingatkan kepada siswa dengan memberikan pertanyaan terkait etika berjalan kaki dan menyeberang jalan. Siswa akan merespon pertanyaan fasilitator dengan menjawab pertanyaan dengan tetap berjalan berbanjar. Hal ini dapat mengalihkan perhatian siswa untuk tidak saling bersenda gurau dan berjalan bersebelahan.

Kondisi pedestrian di depan sekolah yang bagus, tersedianya street furniture dan signage membuat siswa merasa aman ketika akan berangkat atau pulang sekolah dengan berjalan kaki (Gambar 4). Jalur pejalan kaki yang aman merupakan salah satu elemen fisik yang penting untuk mempromosikan kebiasaan berjalan kaki bagi anak sekolah (Ipingbemi dan Aiworob 2013).

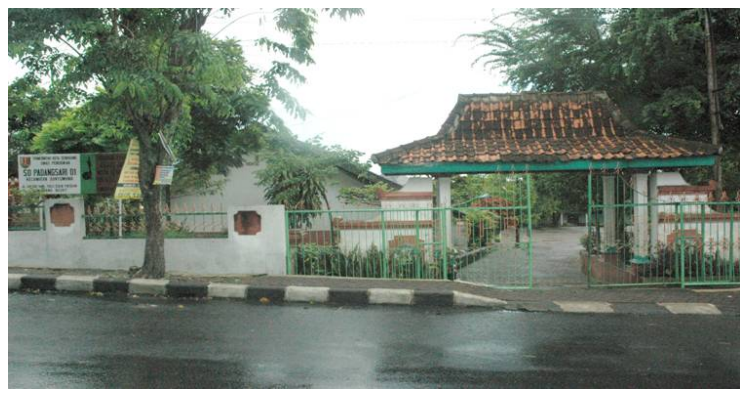

a

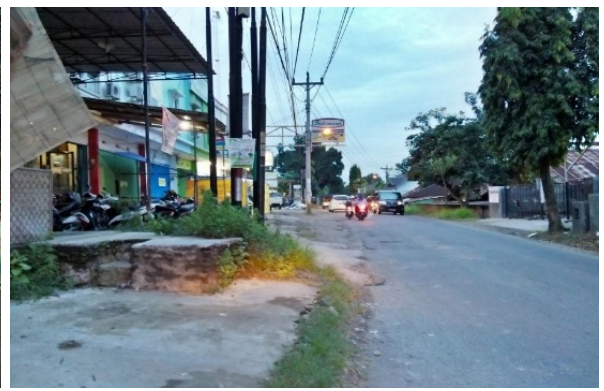

b

Gambar 4 5a. Lokasi SDN Pedalangan 01, Banyumanik, 5b. Jalur Pedestrian di Kawasan Pedalangan, Banyumanik

Sumber : Dokumentasi Penulis, 2020

Anak-anak sangat rentan untuk mengalami kecelakaan ketika menyebrang jalan karena mereka memiliki pengetahuan lalu lintas yang minim (Ipingbemi dan Aiworob 
2013), keterampilan fisik dan kognitif mereka tidak sepenuhnya berkembang dan kondisi fisik mereka yang lebih kecil membuat anak-anak sulit untuk dilihat ketika berada di jalan (Peden et al., 2004). Menyebrang jalan merupakan tugas yang rumit karena melibatkan perhatian, persepsi, dan kemampuan motorik (Corbett \& Morrongiello, 2017). Siswa SD Pedalangan telah memahami etika menyebrang jalan dengan baik. Mereka mencontoh orang tua/saudara/orang dewasa ketika menyebrang jalan (Berry \& Romo, 2006). Berdasarkan hasil penelitian Holm et al., (2018) mengungkapkan bahwa orang tua adalah panutan terpenting bagi siswa dalam berperilaku di jalan.

Siswa SD Pedalangan yang akan menyebrang jalan telah memperhatikan arus lalu lintas kendaraan dari sisi kanan dan kiri sebelum mereka menyebrang. Materi yang diberikan kepada siswa ketika menyebrang jalan adalah mengusahakan dan membiasakan siswa untuk melalui zebra cross atau jembatan penyebrangan ketika akan menyebrang jalan. Apabila tidak tersedia fasilitas menyebrang jalan siswa telah memahami untuk memilih menyebrang di tengah jalan daripada di sudut jalan, berhenti di trotoar dan melambai kepada pengemudi sebelum menyeberang jalan, tetap waspada dan mendengarkan mobil ketika mulai menyeberang jalan dan tidak berlari ketika menyebrang jalan. Di Yordania, hampir setengah dari anak-anak yang menyeberang jalan tidak memeriksa lalu lintas sebelum atau saat menyeberang (Kdanela 1993).

Apabila arus kendaraan ramai, dan mereka menjumpai orang dewasa berada di sekitar mereka, mereka akan meminta tolong untuk menyebrangkan mereka. Namun kondisi ini jarang terjadi. Orang dewasa yang melihat anak kesulitan ingin menyebrang jalan akan secara langsung membantu mereka menyebarang. Hal ini akan mengurangi resiko kecelakan pada anak anak ketika menyebrang jalan (Berry \& Romo, 2006). Namun, terdapat beberapa siswa yang enggan/malu meminta tolong kepada orang dewasa yang berada di sekitarnya. Melalui pelatihan menyebrang jalan ini, mereka lebih berani untuk meminta tolong kepada orang dewasa untuk menyebrang jalan ketika arus lalu lintas sangat ramai.

Bagi siswa yang menggunakan sepeda ke sekolah, mereka juga telah memahami cara untuk menyebrang. Siswa - siswa yang bersepeda biasanya akan menyebrang secara komunal. Kebiasaan siswa SD Pedalangan yang berkelompok bagi mereka yang menggunakan sepeda membuat menyebrang jalan bukan suatu masalah. Menurut mereka, kendaraan akan lebih mudah berhenti dan mempersilahkan mereka menyebrang ketika terdapat beberapa siswa bersepeda antri untuk menyebrang jalan. 
Perbedaan yang terlihat sebelum dan setelah dilakukan teaching pedestrian kepada siswa SD Pedalangan adalah pemahaman siswa terhadap etika berada di jalur pejalan kaki dan menyebrang jalan bertambah. Sebelum dilakukan pelatihan, siswa hanya paham mengenai berjalan harus di sebelah kiri, menjaga sopan dan santun, memperhatikan rambu lalu lintas, berhati - hati terhadap kendaraan dan orang yang tidak dikenal, dan tidak membuang sampah sembarangan. Setelah dilakukan teaching pedestrian siswa dapat lebih memahami tentang cara berjalan harus berbanjar, tidak bersenda gurau di jalan, membiasakan mengucap salam atau memberikan senyuman ketika akan mendahului orang tua maupun kepada orang yang sedang berpapasan kepada mereka,tidak menyebrang di sudut jalan, berhenti di trotoar dan melambai kepada pengemudi sebelum menyeberang jalan dan waspada ketika mulai menyeberang jalan, tidak berlari ketika menyebrang jalan serta berani meminta pertolongan kepada orang dewasa untuk menyebrang jalan ketika arus kendaraan sedang ramai.

Adanya edukasi kepada siswa SD Pedalangan diharapkan dapat membuat pemahaman siswa tentang etika berjalan dan menyebrang jalan lebih dapat dipahami dan dipraktekan. Pemahaman siswa tentang keselamatan berjalan dijalan baik ketika menuju sekolah atau ke tempat umum lain seperti taman/taman bermain dapat mengurangi resiko terjadinya kecelakaan anak di jalan (McLaughlin et al., 2019). Sosialisasi dan pelatihan tentang etika berjalan dan menyebrang jalan kepada anak yang telah diterapkan di sekolah, terbukti menjadi prosedur yang efektif untuk mengajarkan keterampilan keselamatan pejalan kaki kepada anak TK hingga SD kelas enam (Miller et al., 2004). Upaya merancang program pendidikan berbasis pembelajaran aktif untuk memperbaiki perilaku anak ketika menyeberang jalan diperlukan juga keterlibatan orang tua (Zare, Niknami, Heidarnia, \& Fallah, 2019).

\section{KESIMPULAN DAN SARAN}

\subsection{Kesimpulan}

Pengajaran tentang etika berjalan dan menyebrang jalan kepada siswa di SD Pedalangan telah mampu meningkatkan pemahaman siswa. Pendidikan keselamatan pejalan kaki harus dipertimbangkan masuk dalam pelajaran formal disekolah karena pemahaman siswa tentang keselamatan berjalan akan dapat mengurangi resiko kecelakaan bagi anak (McLaughlin et al., 2019; Holm et al., 2018). Studi pengamatan ini sangat berharga dalam hal mengidentifikasi kebiasaan yang dilakukan oleh anak - anak ketika 
sedang berjalan dan menyebrang jalan. Hal ini akan membantu bagi orang dewasa untuk mengajari cara berperilaku di jalan maupun cara menyebrang jalan (Zeedyk, Wallace, \& Spry, 2002).

\subsection{Sarana}

Kawasan sekolah SD Pedalangan Kecamatan Banyumanik memiliki potensi untuk dikembangkan sebagai sentra pendidikan yang ramah lingkungan. Kondisi ini dapat dilihat dari adanya jalur pejalan kaki yang cukup dengan street furniture dan signage yang bermanfaat bagi anak - anak (Johansson, Martensson, Janssonc, \& Sternudd, 2020). Pemahaman siswa SD Pedalangan yang semakin meningkat tentang etika pejalan kaki dan menyebrang jalan juga menjadi salah satu potensi untuk mendukung kawasan dijadikan sebagai sentra pendidikan yang ramah lingkungan.

Adanya penelitian ini diharapkan dapat memberikan kontribusi terhadap pengajaran kepada anak - anak tentang keselamatan berjalan di jalur pejalan kaki dan di ruang publik. Pemahaman siswa yang semakin meningkat tentang etika berjalan di jalur pejalan kaki diharapkan dapat mempengaruhi anak - anak lain untuk mau berjalan kaki ke sekolah atau ruang publik.

\section{DAFTAR PUSTAKA}

Berry, D. S., \& Romo, C. V. (2006). Should 'Cyrus the Centipede' take a hike? Effects of exposure to a pedestrian safety program on children's safety knowledge and selfreported behaviour. Safety Research, 37(4), $333 \quad 341$. https://doi.org/10.1016/j.jsr.2006.05.003

Bull, A. (Ed.). (2004). Traffic Congestion the Problem and How to Deal With It. Santiago: United Nation.

Corbett, M. R., \& Morrongiello, B. A. (2017). Examining how different measurement approaches impact safety outcomes in child pedestrian research: Implications for research and prevention. Accident Analysis and Prevention, 106, 297-304. https://doi.org/10.1016/j.aap.2017.06.002

Creswell, J. W. (2014). Research design: qualitative, quantitative, and mixed methods approaches (4th Editio). United States Of America: SAGE Publications, Inc.

DiMaggio, C., Frangos, S., \& Li, G. (2016). National Safe Routes to School program and risk of school-age pedestrian and bicyclist injury. Annals of Epidemiology, 26(6), 
412-417. https://doi.org/10.1016/j.annepidem.2016.04.002

Dong, X., Peek-Asa, C., Yang, J., Wang, S., Chen, X., Chi, G., \& Ramirez, M. (2010). The association of road safety knowledge and risk behaviour with paediatric road traffic injury in Guangzhou, China. Injury Prevention, 17, 15-20. https://doi.org/10.1136/ip.2010.027540

Dumbaugha, E., Li, W., \& Joh, K. (2013). The built environment and the incidence of pedestrian and cyclist crashes. URBAN DESIGN International, 18(3), 217-228. https://doi.org/10.1057/udi.2013.2

Gatersleben, B., \& Uzzell, D. (2007). Affective Appraisals of the Daily Commute: Comparing Perceptions of Drivers, Cyclists, Walkers, and Users of Public Transport. Environment and Behavior, 39(3), 416-431. https://doi.org/10.1177/0013916506294032

Grayson, G. B. (1981). The identifiction of training objectives: What shall we tell the children? Accident Analysis \& Prevention, 13(3), 169-173. https://doi.org/10.1016/0001-4575(81)90003-8

Holm, A., Jaani, J., Eensoo, D., \& Piksööt, J. (2018). Pedestrian behaviour of 6th grade Estonian students: Implications of social factors and accident-prevention education at school. Transportation Research Part F: Traffic Psychology and Behaviour, 52, 112 119. https://doi.org/10.1016/j.trf.2017.11.005

Hwang, J., Joh, K., \& Woo, A. (2017). Social inequalities in child pedestrian traffic injuries: Differences in neighborhood built environments near schools in Austin, TX, USA. Journal of Transport \& Health, 6, 40-49. https://doi.org/10.1016/j.jth.2017.05.003

Ipingbemi, O., \& Aiworob, A. B. (2013). Journey to school, safety and security of school children in Benin City, Nigeria. Transportation Research, 19, 77-84. https://doi.org/10.1016/j.trf.2013.03.004

Jermprapai, K., \& Srinivasan, S. (2014). Planning-Level Model for Assessing Pedestrian Safety. Transportation Research Record: Journal of the Transportation Research Board, 2464(1), 109-117. https://doi.org/10.3141/2464-14

Johansson, M., Martensson, F., Janssonc, M., \& Sternudd, C. (2020). Urban space for children on the move. In Transportation and Children's Well-Being (pp. 217-235). https://doi.org/10.1016/b978-0-12-814694-1.00012-9

Kandela, P. (1993). Road accidents in Jordan. The Lancet, 346(8868), 426. 
Jurnal Planologi Vol. 17 No. 1, April 2020

Available: http://jurnal.unissula.ac.id/index.php/psa

https://doi.org/10.1016/0140-6736(93)92824-D

Koekemoer, K., Gesselleen, M. Van, Niekerk, A. Van, Govender, R., \& As, A. B. Van. (2017). Child pedestrian safety knowledge, behaviour and road injury in Cape Town, South Africa. Accident Analysis and Prevention, 99, 202-209. https://doi.org/10.1016/j.aap.2016.11.020

McLaughlin, C. M., Barry, W. E., Barin, E. N., Mert, M., Lowery, C., Upperman, J. S., ... Arbogast, H. (2019). Interactive Education is Associated With Lower Incidence of Pedestrian Related Injury in Children. Journal of Surgical Research, 244, 57-62. https://doi.org/10.1016/j.jss.2019.06.015

Miller, J. A., Austin, J., \& Donrohn. (2004). Teaching Pedestrian Safety Skills to Children. Environment and Behavior, 36, 368-385. https://doi.org/10.1177/0013916503260880

Page, T., Iwata, B., \& Neef, N. (1976). Teaching pedestrian skills to retarded persons: Generalization from the classroom to the natural environment. Journal of Applied Behavior Analysis, 9, 433-444. https://doi.org/10.1901/jaba.1976.9-433

Peden, M., Scurfield, R., Sleet, D., Mohan, D., Hyder, A. A., Jarawan, E., \& Mathers, C. (Eds.). (2004). World report on road traffic injury prevention. Geneva: World Health Organization.

R.Bishop, K. (1989). Designing Urban Corridors. APA Planning Advisory Service.

Rubenstein, H. M. (1992). Pedestrian Malls, Streetscopes and Urban Spaces. New York: John Wiley \& Sons, Inc.

Samadikun, B. P., Sudibyakto, Setiawan, B., \& Rijanta. (2014). The Impact Development of Education Area in Tembalang Semarang Jawa Tengah. Manusia Dan Lingkungan, 21, 366-376. https://doi.org/10.22146/jml.18565

Schwebel, D. C., Wu, Y., Swanson, M., Cheng, P., Ning, P., Cheng, X., ... Hu, G. (2018). Child pedestrian street-crossing behaviors outside a primary school: Developing observational methodologies and data from a case study in Changsha, China. Journal of Transport \& Health, 8, 283-288. https://doi.org/10.1016/j.jth.2018.01.005

Ujianti, R. M. D. (2012). Penggunaan Jalur Pedestrian Sebagai Perwujudan Kota Berkelanjutan (Studi Kasus: Akses Utama Kampus Universitas Diponegoro Tembalang Semarang). Universitas Diponegoro.

Wang, H., Tan, D., Schwebel, D. C., Shi, L., \& Miao, L. (2018). Effect of age on children's pedestrian behaviour: Results from an observational study. Transport Research Part F, 58, 556-565. https://doi.org/10.1016/j.trf.2018.06.039 
Jurnal Planologi Vol. 17 No. 1, April 2020 Available: http://jurnal.unissula.ac.id/index.php/psa

Zare, H., Niknami, S., Heidarnia, A., \& Fallah, M. H. (2019). Traffic safety education for child pedestrians: A randomized controlled trial with active learning approach to develop streetcrossing behaviors. Transportation Research Part F: Traffic Psychology and Behaviour, 60(734-742). https://doi.org/10.1016/j.trf.2018.10.021

Zeedyk, M. S., \& Kelly, L. (2003). Behavioural observations of adult-child pairs at pedestrian crossings. Accident Analysis \& Prevention, 35(5), 771-776. https://doi.org/10.1016/s0001-4575(02)00086-6

Zeedyk, M. S., Wallace, L., \& Spry, L. (2002). Stop, look, listen, and think? Accident Analysis \& Prevention, 34(1), 43-50. https://doi.org/10.1016/s0001-4575(00)00101-9 